\title{
Synthesis of a 2'-Se-Uridine Phosphoramidite and Its Incorporation into Oligonucleotides for Structural Study
}

\author{
Jozef Salon, Guexiong Chen, Yoani Portilla, Markus W. Germann, and Zhen Huang \\ Department of Chemistry, Georgia State University, Atlanta, GA 30303, \& Brooklyn College, \\ Brooklyn, NY 11210, USA
}

\begin{abstract}

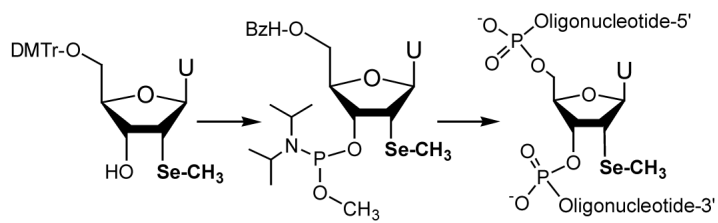

We report here the synthesis of the $5^{\prime}$-[benzhydryloxy-bis(trimethylsilyloxy)] silyl-2' methylseleno-2'-deoxyuridine phosphoramidite and its incorporation into oligonucleotides by solid-phase synthesis. The coupling yield of this phosphoramidite into oligonucleotides is higher than $99 \%$. We also demonstrate that this $2^{\prime}$-methylseleno-phosphoramidite is compatible with the $5^{\prime}$-silyl-2' -ACE chemistry, for longer Se-RNA solid-phase synthesis. Our preliminary NMR study on the synthesized $2^{\prime}$-Se-DNA has revealed a $\mathrm{U}_{\mathrm{Se}}-\mathrm{A}$ base pair and a duplex structure formation when its complementary strand was present.
\end{abstract}

Nucleic acids are important bio-macromolecules in living systems and are involved in genetic information storage, expression, and regulation. Chemical modifications and structural studies have helped to reveal many insights on their biological functions and mechanisms. ${ }^{1-5}$ To get insights of the structure and function of nucleic acids, we have recently developed selenium derivatization of DNA and RNA for phase determination, ${ }^{6-10}$ a long-standing problem, ${ }^{11}$ in X-ray crystallography. We have incorporated selenium atoms into nucleic acids chemically and enzymatically by replacing the nucleotide oxygen, such as the $5^{\prime}, 2^{\prime}$, and non-bridging phosphate oxygen atoms ${ }^{6,9,12}$ for X-ray crystal structure determination. Recently, several crystal structures of DNA and RNA molecules derivatized with the Se-labeling strategy have been reported by several laboratories using multiwavelength anomalous dispersion (MAD) phasing. ${ }^{8}, 13,14$

Our early experimental results on the structural determination of the Se-oligonucleotides by $\mathrm{X}$-ray crystallography indicated that the $2^{\prime}$-Se modification favors the sugar pucker with the $2^{\prime}$-exo conformation, which is identical to that of A-form DNA or RNA. ${ }^{8}$ Reliable and efficient synthesis of longer RNAs with this $2^{\prime}$-Se modification is desirable for X-ray crystal structural studies of catalytic RNAs. Preparation of longer RNAs with this Se-derivatization is currently achieved via chemical synthesis of short RNA fragements and enzymatic ligation of these synthesized fragments. ${ }^{15}$ This approach requires several purification steps and ligation steps, which is labor-intensive and also suffers low yield. Obviously, the current

*Huang@gsu.edu.

Supporting Information Available: Experimental procedures, ${ }^{1} \mathrm{H}$ and ${ }^{13} \mathrm{C}$ NMR, HPLC, and HRMS analytical data. This material is available free of charge via the Internet at http://pubs.acs.org. 
strategy is not practical for routine synthesis of large quantity (several miligrames) of longer RNAs, which limits the wide applications of the Se-derivatization of longer functional RNAs.

As the $5^{\prime}$-silyl-2'-ACE chemistry is currently the most effective strategy for synthesizing longer RNAs, ${ }^{16,17}$ we have recently explored this ACE chemistry using the previously developed $5^{\prime}$-O-DMTr-2' -Se-Me uridine and cytidine phosphoramidites. ${ }^{7,}{ }^{10}$ Due to differences in the $5^{\prime}$-deprotection and phosphite oxidation steps, however, these two Sephosphoramidites could not be conveniently used in the $5^{\prime}$-silyl-2' -ACE chemistry. To overcome these shortcomings and to meet the needs of longer Se-RNA synthesis, we have synthesized $5^{\prime}$-benzhydryl-2' -methylseleno phosphoramidite (4, Scheme 1$)$. This development allows milligram-scale synthesis of longer RNAs derivatized with selenium, without ligation. Similarly, this synthesis can be extended to syntheses of the other three Sederivatized phosphoramidites (A, C and G) for the ACE chemistry. In order to conveniently demonstrate that $5^{\prime}$-BzH-2 ${ }^{\prime}$-Se-uridine phosphoramidite 4 is compatible with $5^{\prime}$-silyl-2' ACE chemistry, syntheses of $2^{\prime}$-Se-RNAs and $2^{\prime}$-Se-DNAs were designed as a model system to examine the compatibility of $\mathbf{4}$ with the reagents and conditions used in the $5^{\prime}$ silyl-2'-ACE chemistry. The synthesized Se-DNAs were also studied by NMR to obtain the insight of duplex formation.

We report here the synthesis of the $5^{\prime}-\mathrm{O}-\mathrm{BzH}-2^{\prime}$-Se-Me uridine phosphoramidite (4), its incorporation into oliognucleotides via solid-phase synthesis, and Se-DNA duplex study by NMR. Uridine derivative 1, synthesized previously, ${ }^{10}$ was treated with $80 \%$ acetic acid to remove the $5^{\prime}$-DMTr group (96\% yield), followed by protection of the $5^{\prime}$-hydroxy group with benzhydryloxybis(trimethylsilyloxy)silyl $(\mathrm{BzH})$ group using $\mathrm{BzH}-\mathrm{Cl}$ in dry DMF (86\% yield). ${ }^{17}$ Partially protected uridine derivative $\mathbf{3}$ was converted to the corresponding phosphoramidite 4 in dry $\mathrm{CH}_{2} \mathrm{Cl}_{2}$ solvent using bis( $N, N$-diisopropylamino)methoxy phosphine (DIPAMP) in the presence of 5-(benzylthio)- $1 H$-tetrazole (88\% yield). ${ }^{10}, 17$

The incorporation cycle of phosphoramidite 4 in oligonucleotide solid-phase synthesis ${ }^{10}$ was modified in order to successfully synthesize the $2^{\prime}$-Se-derivatized DNAs and RNAs, which also served as testing models for the compatibility with $5^{\prime}$-silyl-2' - ACE chemistry. These following modifications represent the reagents and treatments in the $5^{\prime}$-silyl-2 ${ }^{\prime}$-ACE chemistry. First, 5-benzylmercapto- $1 H$-tetrazole was used as the reagent for the coupling reaction of phosphoramidite $4,{ }^{18}$ instead of $1 H$-tetrazole. Second, after the coupling of Semodified phosphoramidite 4 , we examined the phosphite oxidation with tert-butyl hydroperoxide (BHPO) in toluene for 45 seconds. ${ }^{17}$ This BHPO treatment did not cause oxidation of the $2^{\prime}$-selenide-functionality, which is consistent with the iodine oxidation. ${ }^{10}$ MS and HPLC analyses indicated that the selenide oxidation was not detectable (Fig. 1 and 2). Third, the $5^{\prime}$-BzH deprotection was performed with triethylammonium fluoride in DMF for 60 seconds, instead of the $5^{\prime}$-DMTr deprotection with $3 \%$ trichloroacetic acid. Fourth, after the oligonucleotide synthesis was completed, the immobilized oligonucleotides were treated with disodium 2-carbamoyl-2-cyanoethylene-1,1-dithiolate trihydrate ${ }^{17}$ in DMF for 15 minutes to remove the methoxy group on the 3 -phosphate group of the Se-modified nucleotide, followed by water and acetonitrile washing. Finally, the oligonucleotide RNAs and DNAs containing the $2^{\prime}$-Se-derivatization were cleaved off the support and fully deprotected with concentrated ammonia at $55^{\circ} \mathrm{C}$ overnight for DNAs and with methylamine for RNAs. ${ }^{10}$ The stability of the Se-oligonucleotides under these conditions and treatments used in the $5^{\prime}$-silyl-2 ${ }^{\prime}$-ACE chemistry indicates the compatibility of this Se-uridine phosphoramidite (4) with the ACE chemistry for RNA synthesis.

The crude 2 '-Se-derivatized DNA and RNA oligonucleotides with DMTr-on were analyzed by HPLC. Representative reversed-phase HPLC elution profiles are shown in Figure 1. Less 
than $7 \%$ short oligonucleotides were formed on average, which suggested a high coupling yield per synthetic cycle (higher than $99 \%$ on average). As expected, the coupling yields of this Se-phosphoramidite in both Se-DNA and Se-RNA syntheses are the same due to the almost identical coupling of the Se-phosphoramidite incorporation into both Se-DNA and Se-RNA. The synthesized oligonucleotides were purified twice by HPLC (DMTr-on and DMTr-off). The reversed-phase HPLC purification was performed by a Zorbax C18 column $(21 \times 250 \mathrm{~mm})$, eluted $(10 \mathrm{~mL} / \mathrm{min})$ with a linear gradient from buffer $\mathrm{A}(20 \mathrm{mM}$ triethylammonium acetate, $\mathrm{pH} 7.1)$ to $100 \%$ buffer B (50\% acetonitrile, $20 \mathrm{mM}$ triethylammonium acetate, $\mathrm{pH}$ 7.1) in $30 \mathrm{~min}$. These oligonucleotides were also confirmed by MS analysis. Typical MS spectra of DMTr-off DNAs and RNAs are shown in Figure 2, and all MS data are collected in Table 1.

In order to understand the effect of Se-modification on oligonucleotide structure, we examined the consequence of a single derivatization. The host DNA duplex forms a B type duplex with 9 base pairs ( $5^{\prime}$-GAGCTCCAT- $3^{\prime}$ and $5^{\prime}$-ATGGAGCTC- $3^{\prime}$, Fig. $\left.3 \mathrm{~A}\right) .{ }^{19}$ Figure 3 shows the imino proton NMR spectra of the unmodified host duplex, the Semodified duplex and the constituent strands. The Se-modified single strand $\left(5^{\prime}-\right.$ GAGCU $_{\mathrm{Se}} \mathrm{CCAT}-3^{\prime}$ ) is largely unstructured in solution (Fig. 3B), while the complement strand (Fig. 3C) exhibits some base pair formation by itself, indicative of homoduplex formation. In the presence of the Se-modified counter part, however, the heteroduplex is formed (Fig. 3D). The minor peak observed at $14.05 \mathrm{ppm}$ in Figure 3D indicates the presence of small amount of homoduplex. Although the Se-modified duplex is thermodynamically less stable than the control duplex, we clearly observe the presence of 9 base pairs. The imino protons of the $5 \mathrm{G}-\mathrm{C}$ base pairs resonate at 12.6-12.9 ppm, while the 3 $\mathrm{A}-\mathrm{T}$ and $1 \mathrm{~A}-\mathrm{U}_{\mathrm{Se}}$ base pairs are in the region of $13-14.3 \mathrm{ppm}$. As anticipated, the spectrum of the control duplex (5 G-C and 4 A-T, Fig. 3A) is similar to the modified duplex. Especially, the chemical shifts of 1,2,8 A-T base pairs remain the same. While the chemical shift of the no. 5 A-T imino proton in native duplex is at $13.9 \mathrm{ppm}$, the modified $\mathrm{A}-\mathrm{U}_{\mathrm{Se}}$ base pair is at $13.7 \mathrm{ppm}$. This chemical shift demonstrates that the central Semodified $\mathrm{U}$ is capable of base pairing with $\mathrm{A}$ in the context of a B type host duplex. This comparison of the Se-modidified and control duplexes reveals that the Se-modification does not cause significant perturbation, which is consistent with the UV-melting temperature study. ${ }^{12}$ Further NMR study will reveal the structural nature of the modified duplex.

In conclusion, we have synthesized the $2^{\prime}$-Se-uridine phosphoramidite (4). More importantly, we have successfully incorporated it into oligonucleotides with a high coupling yield (over 99\%). As expected, the $2^{\prime}$-Se-functionality is stable under the conventional oligonucleotide synthesis, indicated by HPLC and MS analyses. We have also demonstrated that this phosphoramidite (4) and the synthesized $2^{\prime}$-Se-oligonucleotides are stable and compatible with the reagents used in the $5^{\prime}$-silyl-2' ${ }^{\prime}$-ACE chemistry for RNA synthesis. As longer Se-RNA synthesis with satisfactory quantity and quality is desired in studying functional RNAs, this phosphoramidite (4) meets the need in site-specific RNA derivatization with selenium in X-ray crystal structure study of longer RNAs. ${ }^{20}$

Our NMR data demonstrate the formation of a DNA duplex structure in aqueous solution between the $2^{\prime}$-Se- $\mathrm{U}$ modified sequence and its unmodified complementary strand. The $\mathrm{U}_{\mathrm{Se}}-\mathrm{A}$ base pair formation is consistent with our previous crystal structure study. ${ }^{8}$ Further NMR experiments will provide conformation parameters of $2^{\prime}$-Se derivatized nucleotides in solution and will also help in determining optimal positions of Se derivatization for nucleic acid X-ray crystal structure study. Moreover, our results have suggested that the $2^{\prime}$-Se-labels can be useful in NMR spectrum assignment and structure determination, especially for longer RNAs (over $60 \mathrm{nt}$.). The selenium derivatization of DNA and RNA will significantly facilitate structure and mechanism studies of nucleic acids. 


\section{Supplementary Material}

Refer to Web version on PubMed Central for supplementary material.

\section{Acknowledgments}

This work was supported by GSU Research Program and the U.S. National Institute of Health (GM069703). We thank Dr. Abdalla Hassan and Julianne Caton-Williams for carefully reading this manuscript.

\section{References}

(1). Adams PL, Stahley MR, Kosek AB, Wang J, Strobel SA. Nature. 2004; 430:45-50. [PubMed: 15175762]

(2). Ban N, Nissen P, Hansen J, Moore PB, Steitz TA. Science. 2000; 289:905-920. [PubMed: 10937989]

(3). Benoff B, Yang H, Lawson C, Parkinson G, Liu J, Blatter E, Ebright YW, Berman HM, Ebright RH. Science. 2002; 297:1562-1566. [PubMed: 12202833]

(4). Suryadi J, Tran EJ, Maxwell ES, Brown, B. A II. Biochemistry. 2005; 44:9657-9672. [PubMed: 16008351]

(5). Haeberli P, Berger I, Pallan PS, Egli M. Nucleic Acids Res. 2005; 33:3965-3975. [PubMed: 16027443]

(6). Carrasco N, Ginsburg D, Du Q, Huang Z. Nucleosides Nucleotides Nucleic Acids. 2001; 20:17231734. [PubMed: 11580197]

(7). Du Q, Carrasco N, Teplova M, Wilds CJ, Egli M, Huang Z. J. Am. Chem. Soc. 2002; 124:24-25. [PubMed: 11772055]

(8). Teplova M, Wilds CJ, Wawrzak Z, Tereshko V, Du Q, Carrasco N, Huang Z, Egli M. Biochimie. 2002; 84:849-858. [PubMed: 12458077]

(9). Carrasco N, Huang Z. J. Am. Chem. Soc. 2004; 126:448-449. [PubMed: 14719925]

(10). Carrasco N, Buzin Y, Tyson E, Halpert E, Huang Z. Nucleic Acids Res. 2004; 32:1638-1646. [PubMed: 15007109]

(11). Holbrook SR, Kim S-H. Biopolymers. 1997; 44:3-21. [PubMed: 9097731]

(12). Buzin Y, Carrasco N, Huang Z. Organic Letter. 2004; 6:1099-1102.

(13). Wilds CJ, Pattanayek R, Pan C, Wawrzak Z, Egli M. J. Am. Chem. Soc. 2002; 124:1491014916. [PubMed: 12475332]

(14). Serganov A, Keiper S, Malinina L, Tereshko V, Skripkin E, Höbartner C, Polonskaia A, Phan AT, Wombacher R, Micura R, Dauter Z, Jäschke A, Patel D. J. Nat. Struct. Mol. Biol. 2005; 12:218-224.

(15)a. Hobartner C, Micura R. J. Am. Chem. Soc. 2004; 126:1141-1149. [PubMed: 14746483] b Hobartner C, Rieder R, Kreutz C, Puffer B, Lang K, Polonskaia A, Serganov A, Micura R. J. Am. Chem. Soc. 2005; 127:12035-12045. [PubMed: 16117544]

(16). Scaringe SA, Wincott FE, Caruthers MH. J. Am. Chem. Soc. 1998; 120:11820-1182.

(17). Scaringe SA. Methods. 2001; 23:206-217. [PubMed: 11243834]

(18). Welz R, Muller S. Tetrahedron Lett. 2002; 43:795-797.

(19). Aramini JM, Kalisch BW, Pon RT, van de Sande JH, Germann MW. Biochemistry. 1996; 35:9355-9365. [PubMed: 8755713]

(20). Holbrook SR. Curr. Opin. Struct. Biol. 2005; 15:302-308. [PubMed: 15963891]

Org Lett. Author manuscript; available in PMC 2013 March 14. 
A.

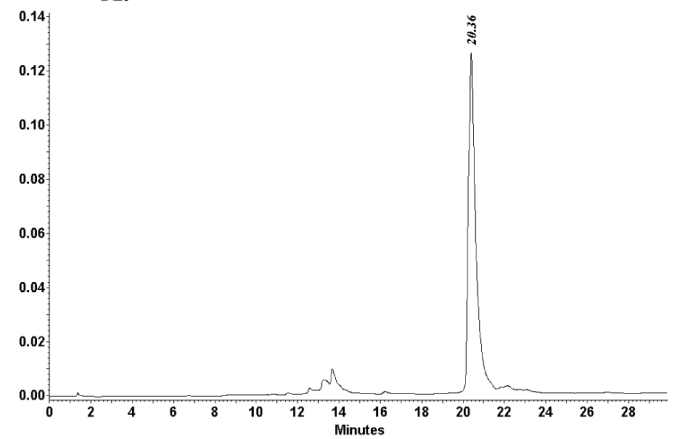

B.

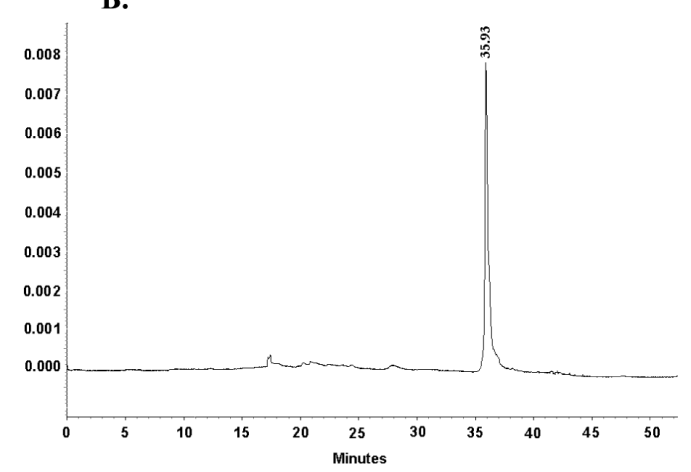

Figure 1.

Reversed-phase HPLC analysis of Se-oligonucleotides. A) crude DMTr-on 2'-Se-DNA (5' DMTr-GAGCU $\mathrm{Se}_{\mathrm{Se}} \mathrm{CAT}-3^{\prime}$ ) after cleavage of the oligonucleotide from the solid support and the deprotection of the bases and backbone. The sample was analyzed on a Zorbax SB-C18 column $(4.6 \times 250 \mathrm{~mm})$, eluted $(1 \mathrm{~mL} / \mathrm{min})$ with a linear gradient from buffer A $(20 \mathrm{mM}$ triethylammonium acetate, $\mathrm{pH} 7.1)$ to $100 \%$ buffer B (50\% acetonitrile, $20 \mathrm{mM}$ triethylammonium acetate, $\mathrm{pH} 7.1$ ) in $30 \mathrm{~min}$. Its retention time is $20.4 \mathrm{~min}$. B) crude DMTr-on 2'-Se-RNA (5' -DMTr-AUGGU $\left._{\mathrm{Se}} \mathrm{GCUC}^{\prime} \mathbf{3}^{\prime}\right)$ after cleavage of the oligonucleotide from the solid support and the deprotection of the bases, $2^{\prime}$-TOM groups, and backbone. The sample was analyzed on the same column with the same buffer A and B. The sample was eluted $(1 \mathrm{~mL} / \mathrm{min})$ with a linear gradient from buffer A to $100 \%$ buffer B in $45 \mathrm{~min}$. Its retention time is $35.9 \mathrm{~min}$. 
A.

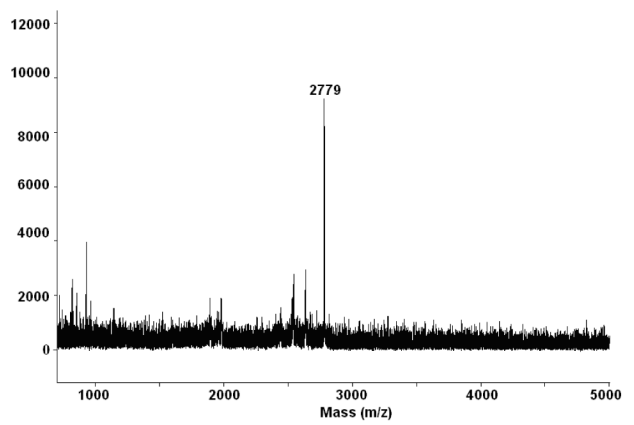

B.

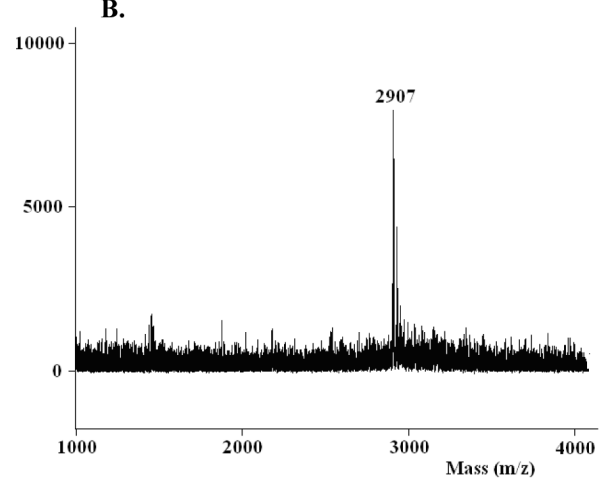

Figure 2.

MALDI-TOF MS analysis of the Se-oligonucleotides. (A) DMTr-off $2^{\prime}$-Se-DNA9mer (5' GAGCU $\mathrm{SeCCAT}{ }^{\prime}$; molecular formula: $\left.\mathrm{C}_{87} \mathrm{H}_{111} \mathrm{~N}_{33} \mathrm{O}_{52} \mathrm{P}_{8} \mathrm{Se}\right)$, FW 2777.8; $[\mathrm{M}+\mathrm{H}]^{+}: 2779$ (calc. 2778.8). (B) DMTr-off $2^{\prime}$-Se-RNA9mer (5' -AUGGU ${ }_{\text {Se-GCUC-3' }}$; molecular formula: $\mathrm{C}_{86} \mathrm{H}_{108} \mathrm{~N}_{32} \mathrm{O}_{62} \mathrm{P}_{8} \mathrm{Se}$ ), FW 2908.7; [M-H] ${ }^{-}: 2907$ (calc. 2907.7). 
$\begin{array}{lllllllll}1 & 2 & 3 & 4 & 5 & 6 & 7 & 8 & 9\end{array}$

$5^{\prime}-\mathrm{A}$ T G G A G C T C-3'

$3^{\prime}-\mathrm{T} A C \mathrm{C} \mathrm{U}_{\mathrm{Se}} \mathrm{C}$ G A G-5'



B

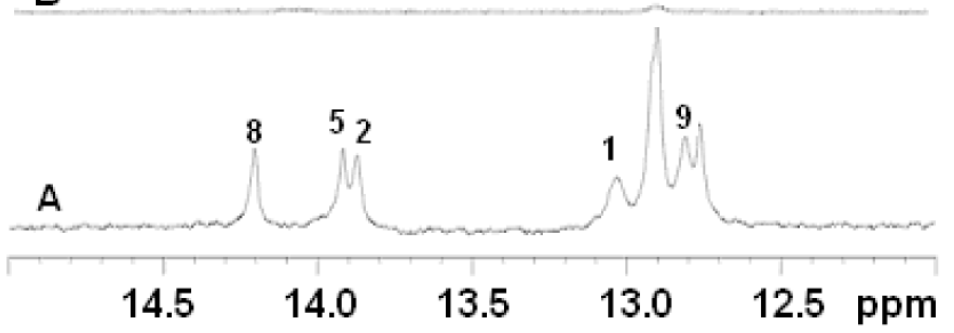

Figure 3.

NMR study of Se-DNA, the complementary strand, and Se-derivatized DNA duplex (100 $\mu \mathrm{M}$ each sequence) in $50 \mathrm{mM} \mathrm{NaCl}, 0.1 \mathrm{mM}$ EDTA, $10 \mathrm{mM} \mathrm{NaH} \mathrm{PO}_{4}-\mathrm{Na}_{2} \mathrm{HPO}_{4}$ (pH 6.5) at $283 \mathrm{~K}$; A). NMR spectrum of the unmodified heteroduplex as a control; B). NMR


ATGGAGCTC-3' single strand; D). NMR spectrum of the modified heteroduplex. 

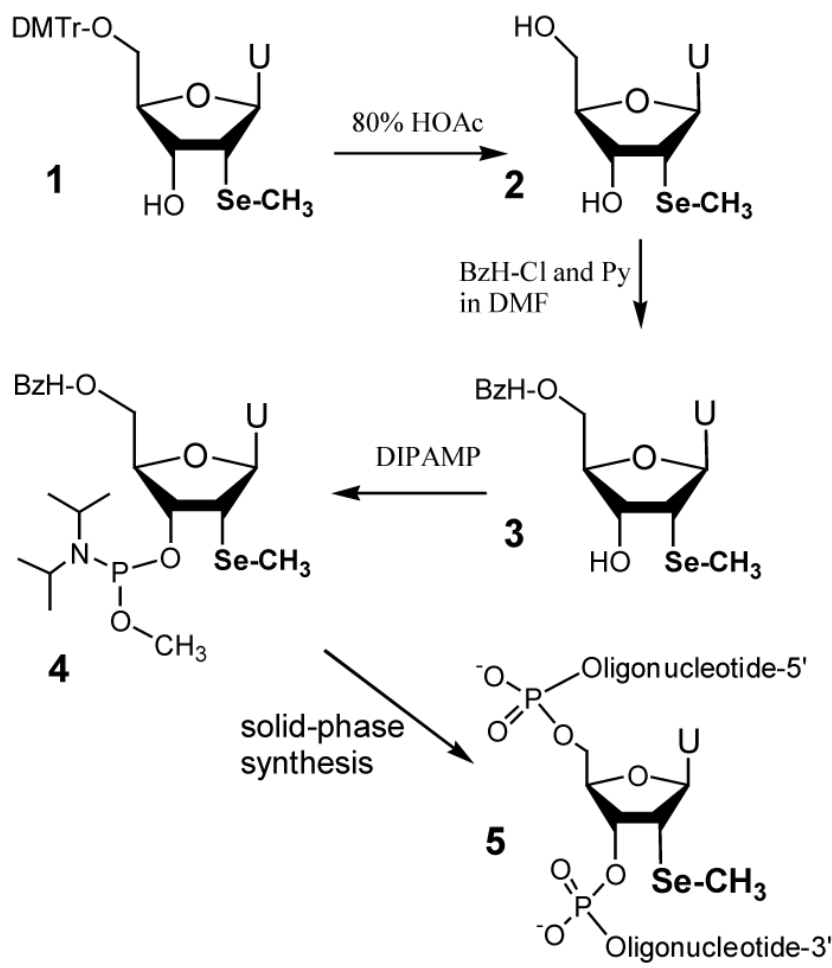

Scheme 1.

Synthesis of $5^{\prime}$-BzH-2' $-\mathrm{Se}-\mathrm{Me}$ uridine phosphoramidite (4) and oligonucleotides containing the Se derivatization (5). 
Table 1

MALDI-TOF MS analytical data of Se-oligonucleotides.

\begin{tabular}{|c|c|c|}
\hline entry & Se-oligonucleotides & measured (calc.) $\mathbf{m} / \mathbf{z}$ \\
\hline a. & $\begin{array}{l}\text { Se-DNA1 } \\
\left(5^{\prime}-\mathrm{GAGCU}_{\mathrm{Se}} \mathrm{CCAT}-3^{\prime}\right) \\
\mathrm{C}_{87} \mathrm{H}_{111} \mathrm{~N}_{33} \mathrm{O}_{52} \mathrm{P}_{8} \mathrm{Se}: \text { FW } 2777.8\end{array}$ & {$[\mathrm{M}+\mathrm{H}]^{+}: 2779(2778.8)$} \\
\hline b. & $\begin{array}{l}\text { Se-DNA2 } \\
\text { non-treated with BHPO } \\
\left(5^{\prime}-\mathrm{ATGGU}_{\mathrm{Se}} \mathrm{GCTC}-3^{\prime}\right) \\
\mathrm{C}_{88} \mathrm{H}_{112} \mathrm{~N}_{32} \mathrm{O}_{54} \mathrm{P}_{8} \mathrm{Se}: \text { FW } 2808.9\end{array}$ & {$[\mathrm{M}+\mathrm{H}]^{+}: 2810(2809.9)$} \\
\hline c. & $\begin{array}{l}\mathrm{Se}-\mathrm{DNA} 2 \\
\text { treated with BHPO } \\
\left(5^{\prime}-\mathrm{ATGGU}_{\mathrm{Se}} \mathrm{GCTC}-3^{\prime}\right) \\
\mathrm{C}_{88} \mathrm{H}_{112} \mathrm{~N}_{32} \mathrm{O}_{54} \mathrm{P}_{8} \mathrm{Se} \text { : FW } 2808.9\end{array}$ & {$[\mathrm{M}+\mathrm{H}]^{+}: 2810(2809.9)$} \\
\hline d. & $\begin{array}{l}\text { Se-DNA3 } \\
\text { non-treated with BHPO } \\
\left(5^{\prime} \text {-CCTU } \mathrm{Se}_{\mathrm{Se}} \mathrm{GACAAAG-3^{ \prime }}\right) \\
\mathrm{C}_{107} \mathrm{H}_{135} \mathrm{~N}_{43} \mathrm{O}_{62} \mathrm{P}_{10} \mathrm{Se}: \text { FW } 3404.2\end{array}$ & $\begin{array}{l}{[\mathrm{M}+\mathrm{H}]^{+}: 3405(3400 \mathrm{avg})} \\
{[\mathrm{M}+\mathrm{Na}]^{+}: 3427(3422 \mathrm{avg})}\end{array}$ \\
\hline e. & $\begin{array}{l}\mathrm{Se}-\mathrm{DNA} 3 \\
\text { treated with BHPO } \\
\left(5^{\prime}-\mathrm{CCTU}_{\mathrm{Se}} \mathrm{GACAAAG}-3^{\prime}\right) \\
\mathrm{C}_{107} \mathrm{H}_{135} \mathrm{~N}_{43} \mathrm{O}_{62} \mathrm{P}_{10} \mathrm{Se}: \mathrm{FW} 3404.2\end{array}$ & $\begin{array}{l}{[\mathrm{M}+\mathrm{H}]^{+}: 3405(3400 \mathrm{avg})} \\
{[\mathrm{M}+\mathrm{Na}]^{+}: 3427(3422 \mathrm{avg})}\end{array}$ \\
\hline f. & $\begin{array}{l}\text { Se-RNA9mer } \\
\text { treated with BHPO } \\
\left(5^{\prime}-\mathrm{AUGGU}_{\left.\mathrm{Se}-\mathrm{GCUC}-3^{\prime}\right)}\right. \\
\mathrm{C}_{86} \mathrm{H}_{108} \mathrm{~N}_{32} \mathrm{O}_{62} \mathrm{P}_{8} \mathrm{Se}: \mathrm{FW} 2908.7\end{array}$ & {$[\mathrm{M}+\mathrm{H}]^{-}: 2907$ (2907.7) } \\
\hline g. & $\begin{array}{l}\text { Se-RNA } 11 \text { mer } \\
\text { treated with BHPO } \\
\left(5^{\prime} \text {-CCUU }{ }_{\mathrm{Se}} \text { GACAAAG- } 3^{\prime}\right) \\
\mathrm{C}_{106} \mathrm{H}_{133} \mathrm{~N}_{43} \mathrm{O}_{72} \mathrm{P}_{10} \text { Se: FW } 3550.1\end{array}$ & {$[\mathrm{M}-\mathrm{H}]^{-}: 3549$ (3549.1) } \\
\hline
\end{tabular}

